\title{
Comparative Evaluation of Some Herbal Therapies for Retained Placenta in Dairy Cows
}

\author{
Anil D. Patil ${ }^{1}$, Sunil K. Sahatpure ${ }^{1}$, Dinesh V. Patil ${ }^{1}$, \\ Ravikanth Kotagiri ${ }^{2}$ and Bhaskar Ganguly ${ }^{2 *}$
}

\author{
${ }^{1}$ Department of Animal Reproduction, Gynecology and Obstetrics, College of Veterinary and \\ Animal Science, MAFSU, Udgir, District, Latur, India \\ ${ }^{2}$ Research and Development Unit, Ayurvet Limited, Baddi, India \\ *Corresponding author
}

\section{Keywords}

AV/UTL/17, AV/UTP/23, Cattle, Fetal membranes, Herbal, Placenta, Retention

\section{Article Info}

Accepted:

04 September 2020 Available Online: 10 October 2020

\section{A B S T R A C T}

The findings of a trial undertaken in dairy cows to evaluate the clinical efficacy of some polyherbal formulations in the management of retention of placenta are reported. Thirty cows were selected for the trial; the animals were divided into six groups, each consisting of five animals. The control group, T0, consisting of animals without retained placenta, was left untreated. In group T1, manual removal of the retained fetal membranes was practiced followed by intrauterine administration of two grams of oxytetracycline. Group T2 was treated orally with AV/UTP/23 premix (M/s Ayurvet Limited, India) @ 40 gtwice on first day, followed by $20 \mathrm{~g}$ twice daily for the next three days. Group T3 was orally administered AV/UTL/17 liquid (M/s Ayurvet Limited, India) @ $50 \mathrm{~mL}$ twice on first day followed by $25 \mathrm{~mL}$ twice daily for the next three days. Group T4 was orally administered Brand A mixed with jaggery @ $100 \mathrm{~g}$ soon after calving and $50 \mathrm{~g}$ thereafter repeated every six hours till the placenta was shed. Group T5 was drenched Brand B @ $100 \mathrm{~mL}$ twice on first day and once daily thereafter for the next three days. The response to the treatments, recorded in terms of the time taken from parturition to complete release of the fetal membranes, was $11.23 \pm 3.2,11.01 \pm 1.1,8.02 \pm 1.2,9.14 \pm 1.22,11.05 \pm 2.2$ and $10.01 \pm$ 1.4 hours in the groups T0, T1, T2, T3, T4 and T5, respectively. Similarly, first postpartum estrus was observed at 90, 60, 70, 85 and 80 days whereas the number of artificial inseminations required for conception was 3, 3, 2, 2, 2 and 2 in groups T0-T5, respectively. 204, 204, 100, 110, 125 and 120 open days were recorded in the groups T0T5, respectively. Overall percentual conception was recorded at nil in the group T0 followed by $60,80,60,60$ and 40 in the groups T1-T5, respectively. Group T2, receiving treatment with AV/UTP/23 premix, showed the best reproductive and production performances. It could be concluded that treatment with herbal products was successful at improving productive and reproductive parameters in dairy cows. Further, among the treatments tested, the use of AV/UTP/23 premix was found most effective for the management of retained placenta under field condition. 


\section{Introduction}

Post-partum period is a crucial transitory phase in bovine life when various physiological, gynecological, and biochemical changes occur. During this period, the animal is exposed to high risk of uterine infections as the anatomical barriers are breached and the genitalia remain open for various days (Goff and Horst, 1997). Retained placenta, also known as retained fetal membrane or retained cleansing, occurs when the calf's side of the placenta, i.e. the fetal membranes, fail to separate from the dam's side. Separation of the membranes normally occurs after the calf is born and early separation can be one of the causes of stillbirth. Normally, expulsion occurs within 3-8 h of the delivery of the calf. The incidence of the problem in healthy dairy cows is $5-15 \%$. The incidence is increased by abortion, particularly with brucellosis or mycotic abortion, dystocia, twin birth, stillbirth, hypocalcemia, high ambient temperatures, advancing age of the cow, premature birth or induction of parturition, placentitis, and nutritional disturbances. Cows with retained fetal membranes are at an increased risk of metritis, displaced abomasum, and mastitis (Gilbert, 2015).

Retention of fetal membranes is mediated by impaired migration of neutrophils to the placental interface in the periparturient period. The impaired neutrophil function extends into the postpartum period and probably mediates the recognized complications of retained fetal membranes. Cows with retained fetal membranes have increased cortisol and decreased estradiol concentrations in late pregnancy. They may also have an altered prostaglandin (PG) E2:PGF2 ratio. Uterine contractility is increased in affected cows. Lack of placental detachment, rather than uterine motility, is responsible for retention of fetal membranes. Once the fetal membranes have been retained in the dam, subsequent infection of the uterus may be largely influenced by the balance between bacterial contamination, and the local and systemic immune status during pregnancy and parturition. Infectious diseases remain more prevalent during this period from an impaired immune status before and immediately after parturition (LeBlanc et al., 2002). Indiscriminate usage of antibiotics for treatment of uterine infections has led to emergence of resistant strains. As a result of overuse and misuse of antibiotics, the focus has now shifted towards alternative treatments viz. herbal medicine (Hemaiswarya et al., 2008; Abdisa, 2018).

The present study was undertaken to compare the efficacy of some polyherbal therapies and conventional antibiotic therapy for the treatment of retained placenta in dairy cows.

\section{Materials and Methods}

The present study was undertaken in 30 dairy cows, divided into 6 equal groups (Table 1), raised at commercial dairy farms located in and around Nagpur, India $\left(21.146^{\circ} \mathrm{N}\right.$, $\left.79.088^{\circ} \mathrm{E}\right)$. The clinical trial, and all interventions and experimental procedures were approved by the Institutional Ethics Committee of the College of Veterinary and Animal Science, MAFSU, Udgir (Approval No. NVC/B-2/1446/16, dated 10.08.2016). Apparently healthy cows, ageing four to eight years, in their second to sixth calving seasons were recruited in the study. All animals were reared under similar environmental and managemental conditions and observed closely before, during and after parturition. The cows were calved in calving pens hygienically and kept in individual pens for 10 days after parturition. Starting as early as possible within 30 minutes of parturition, the calves were allowed to suckle for three days before separation from their dams. Pervaginal examinations were performed to 
detect fetal membranes and lochial discharge from day one until week six post-partum. Perrectal examination of cows was performed until complete involution of the uterus. Both ovaries were examined per-rectally for the detection of ovarian structures. All cows were observed visually twice a day for the detection of estrus.

The parameters recorded were rectal temperature $\left({ }^{\circ} \mathrm{F}\right)$, time elapsed (hours) from parturition to complete release of the fetal membranes, days to first post-partum estrus, number of inseminations required for conception, days open, conception rate, milk yield from days 0-120, and the risk of developing metritis, ketosis and mastitis. Statistical comparisons were made using ANOVA and, unless stated otherwise, all inferences were drawn at $\mathrm{P} \leq 0.05$ (Snedecor and Cochran, 1994).

\section{Results and Discussion}

Retention of fetal membranes in cows is a very serious disorder, which has significant negative influence on health, welfare, milk productivity and further reproduction in the postpartum period (Laven and Peters, 1996). There is reduced milk production, delayed involution of uterus and subsequent delayed conception, early embryonic mortality, and problems like repeat breeding or even permanent infertility (Narasimhan and Deopurkar, 1994). In dairy cows, retained placenta may be the cause of serious economic losses to the farmers as cows with retained placenta may develop bacterial infection, become ill and, thus, suffer from reduced production (Tucho and Ahmed, 2017).

In the present study, the efficacy of some herbal uterine ecbolics and cleansers was evaluated in the management of retained placenta in dairy cows. The results of the study have been summarized in Table 2 . The time taken from parturition to the complete release of the fetal membranes was recorded at $11.23 \pm 3.2,11.01 \pm 1.1,8.02 \pm 1.2,9.14 \pm$ $1.22,11.05 \pm 2.2$ and $10.01 \pm 1.4$ hours in control, T1, T2, T3, T4 and T5, respectively, and a significant difference was observed in the time from parturition to complete release of the fetal membranes among different treatment groups. The time from parturition to complete release of the fetal membranes was significantly lesser in the group $\mathrm{T} 2$ in comparison to all other groups. Walia et al., (2010) reported placental expulsion within 68 hours after treatment with herbal formulations whereas in the present study greater lengths of time were recorded, which may be due to hormonal influence as well as managemental factors. They could also report 83.3\% efficacy of AV/UTL/17 with complete recovery in 10 of 12 cows suffering from either retained placenta, endometritis or postpartum anestrus.

Both hormonal and non-hormonal approaches have been adopted for the management of retained placenta; herbal formulations have been evaluated by many authors (Abdisa, 2018) and some herbal preparations, such as Exapar, are established to have superior therapeutic efficacy (Srinivas et al., 1998). The use of certain plants and their preparations in fertility regulation, particularly as emmenagogues, and in various other reproductive ailments is very well documented in human Ayurvedic therapy (Perumal et al., 2013). Manual removal of the retained fetal membranes causes an immediate and large but short-lived increase in PGFM, probably due to the physical damage of uterine tissue (Bolinder et al., 1988), often resulting in more frequent and more severe uterine infections. Antibiotics, for example, broad-spectrum, long-acting oxytetracycline, when used to treat the infections, offer good prognosis but the 
animal remains at increased risk of developing the condition again (Jesse et al., 2016). Tetracycline antibiotics, commonly used for intrauterine treatment in cattle, tend to inhibit matrix metalloproteinase (MMPs) and might, therefore, interfere with the normal placental detachment mechanisms (Eiler et al., 1992).

Table.1 Overview of trial design: Five healthy cows without retention of placenta served as control. Twenty-five cows suffering from retention of placenta were assigned to groups T1-T5

\begin{tabular}{|c|c|}
\hline Group $(\mathbf{n}=5)$ & Treatment \\
\hline Control & $\begin{array}{l}\text { Cows dropped their fetal membranes within the first } 6-12 \text { hours after } \\
\text { parturition and did not develop any post-partum clinical disorders }\end{array}$ \\
\hline T1 & $\begin{array}{l}\text { Manual removal of the RFM in addition to intrauterine insertion of } 2 \mathrm{~g} \\
\text { Oxytetracycline }\end{array}$ \\
\hline $\mathbf{T 2}$ & $\begin{array}{l}\text { AV/UTP/23 premix (M/s Ayurvet Limited): } 20 \mathrm{~g} \text {; double dose orally twice on } \\
\text { day } 1 \text { followed by single dose twice daily on days } 2-4\end{array}$ \\
\hline $\mathbf{T 3}$ & $\begin{array}{l}\text { AV/UTL/17 liquid (M/s Ayurvet Limited): } 25 \mathrm{~mL} \text {; double dose orally twice on } \\
\text { day } 1 \text { followed by single dose twice daily on days } 2-4\end{array}$ \\
\hline T4 & $\begin{array}{l}\text { Brand A: } 50 \mathrm{~g} \text {; administer one double dose orally mixed with jaggery } \\
\text { (molasses) or feed soon after calving and single dose repeated after every six } \\
\text { hours till the placenta is shed completely within } 24 \text { hours. }\end{array}$ \\
\hline T5 & $\begin{array}{l}\text { Brand B: } 100 \mathrm{~mL} \text {; single dose orally twice on day } 1 \text { followed by single dose } \\
\text { once daily on days } 2-4\end{array}$ \\
\hline
\end{tabular}

Table.2 Efficacy of herbal products as treatment option for retained placenta in dairy cows

\begin{tabular}{|c|c|c|c|c|c|c|c|c|}
\hline \multirow[t]{2}{*}{ Group $(n=5)$} & \multirow{2}{*}{$\begin{array}{l}\text { Rectal } \\
\text { temp } \\
\left({ }^{\circ} \mathbf{F}\right)\end{array}$} & \multirow{2}{*}{$\begin{array}{l}\text { Parturition to } \\
\text { complete release of } \\
\text { the fetal } \\
\text { membranes (hrs) }\end{array}$} & \multirow{2}{*}{$\begin{array}{l}\text { Days to } \\
\text { first } \\
\text { post- } \\
\text { partum } \\
\text { estrus }\end{array}$} & \multirow{2}{*}{$\begin{array}{l}\text { No. of AI } \\
\text { required } \\
\text { for } \\
\text { conception }\end{array}$} & \multicolumn{2}{|c|}{$\begin{array}{l}\text { Reproductive } \\
\text { parameters }\end{array}$} & \multirow{2}{*}{$\begin{array}{l}\text { Milk yield } \\
\text { from days } \\
0-120\end{array}$} & \multirow[t]{2}{*}{$\begin{array}{l}\text { Incidence of } \\
\text { complications }\end{array}$} \\
\hline & & & & & $\begin{array}{l}\text { Days } \\
\text { open }\end{array}$ & $\begin{array}{l}\text { CR } \\
(\%)\end{array}$ & & \\
\hline CONTROL & 101.5 & $11.23 \pm 3.2^{b}$ & 150 & 3 & 204 & Nil & $8.01 \pm 5.6^{\mathrm{c}}$ & $\begin{array}{l}\text { Mild } \\
\text { endometritis }\end{array}$ \\
\hline T1 & 101.6 & $11.01 \pm 1.1^{b}$ & 90 & 3 & 204 & 60 & $9.23 \pm 1.2^{\mathrm{b}}$ & Nil \\
\hline $\mathbf{T} 2$ & 101.5 & $8.02 \pm 1.2^{\mathrm{a}}$ & 60 & 2 & 100 & 80 & $\begin{array}{ll}10.87 & \pm \\
4.4^{\mathrm{a}} & \end{array}$ & Nil \\
\hline T3 & 101.5 & $9.14 \pm 1.22^{c}$ & 70 & 2 & 110 & 60 & $8.87 \pm 32^{d}$ & Nil \\
\hline T4 & 100.5 & $11.05 \pm 2.2^{b}$ & 85 & 2 & 125 & 60 & $9.53 \pm 3.1^{\mathrm{c}}$ & Nil \\
\hline T5 & 101.4 & $10.01 \pm 1.4^{\mathrm{c}}$ & 80 & 2 & 120 & 40 & $9.11 \pm 4.3^{b}$ & Nil \\
\hline
\end{tabular}

Values bearing identical lower-case superscript do not differ significantly within columns

Besides its immediate negative effects on uterine health, retention of placenta is known to exert detrimental effects on post-partum reproductive and productive performance (Gohar et al., 2018). In the present study, first post-partum estrus was observed on days 150, 90, 60, 70, 85 and 80 in control, T1, T2, T3,
T4 and T5, respectively. Number of inseminations required for conception was recorded at 3, 3, 2, 2, 2, 2 and 2 in control, $\mathrm{T} 1, \mathrm{~T} 2, \mathrm{~T} 3, \mathrm{~T} 4$ and $\mathrm{T} 5$, respectively. Open days were recorded at 204, 204, 100, 110, 125 and 120 days in control, T1, T2, T3, T4 and T5, respectively. Conception rate was 
recorded as nil in control and 60, 80, 60, 60 and $40 \%$ in $\mathrm{T} 1, \mathrm{~T} 2, \mathrm{~T} 3, \mathrm{~T} 4$ and $\mathrm{T} 5$, respectively. Comparatively, group T2 showed better results in terms of reproductive indices than the other groups. Previously, Parmar et al., (2017) recorded a significantly higher conception rate in the AV/UTL/17treated group $(83.33 \%)$ as compared to the untreated control $(60 \%)$. Milk production was recorded from days 0 to 120 ; the average daily yield (litres) was $8.01 \pm 5.6$ in control group, and $9.23 \pm 1.2,10.87 \pm 4.4,8.87 \pm 32$, $9.53 \pm 3.1$ and $9.11 \pm 4.3$ in $\mathrm{T} 1, \mathrm{~T} 2, \mathrm{~T} 3, \mathrm{~T} 4$ and T5, respectively. Clearly, group T2 showed better productive and reproductive performances than the other groups. Kaneko et al., (1997) suggested that the conception rate at first service may not be related to occurrence of retained placenta but the more salient effect was more number of open days. Tucho and Ahmed (2017) also recognized decreased milk production and more open days as the main economic impacts of retained placenta.

There was no incidence of metritis, ketosis or mastitis in any of the treatment groups although mild endometritis could be recorded in the control group. Endometritis is a very common sequel to retained placenta. Antibiotics and estrogens have been used to treat, control or prevent the condition, but they are not routinely effective and may have deleterious side-effects (Peters and Laven, 1996).

In conclusion, the use of some herbal uterine ecbolic and cleansing agents was found to be successful in improvement of the production and reproduction parameters in dairy cows suffering from retained placenta. Based on the findings of the study, it could be concluded that AV/UTP/23 premix @ $20 \mathrm{~g}$ with double dose orally twice on first day followed by single dose twice daily for next three days was effective for the prompt expulsion of retained placenta, and improvement of post-partum reproduction and production in dairy cows.

\section{References}

Abdisa, T. (2018). Mechanism of retained placenta and its treatment by plant medicine in ruminant animals in Oromia, Ethiopia. Journal of Veterinary Medicine and Animal Health, 10(6), 135-147.

Bolinder, A., Seguin, B., Kindahl, H., Bouley, D., and Otterby, D. (1988). Retained fetal membranes in cows: manual removal versus nonremoval and its effect on reproductive performance. Theriogenology, 30(1), 45-56.

Eiler, H., and Hopkins, F. M. (1992). Bovine retained placenta: effects of collagenase and hyaluronidase on detachment of placenta. Biology of reproduction, 46(4), 580-585.

Gilbert, R. O. 2015. Retained Fetal Membranes in Cows. In: MSD Veterinary Manual. URL: https://www.msdvetmanual.com/repro ductive-system/retained-fetalmembranes-in-large-animals/retainedfetal-membranes-in-cows, Accessed on 28.06.2020.

Goff, J. P., and Horst, R. L. (1997). Physiological changes at parturition and their relationship to metabolic disorders1, 2. Journal of dairy science, 80(7), 1260-1268.

Gohar, M. A., Elmetwally, M. A., Montaser, A., and Zaabel, S. M. (2018). Effect of Oxytetracycline Treatment on Postpartum Reproductive Performance in Dairy Buffalo-Cows with Retained Placenta in Egypt. Journal of Veterinary Healthcare, 1(3), 45.

Hemaiswarya, S., Kruthiventi, A. K., and Doble, M. (2008). Synergism between natural products and antibiotics against infectious diseases. Phytomedicine, 
15(8), 639-652.

Jesse, F. F. A., Chung, E. L. T., Abba, Y., Sadiq, M. A., Bitrus, A., Hambali, I. U., and Lila, A. M. (2016). A Case of Retained Placenta in a Dairy Cow. Livestock Research International. 04(04), 25-127.

Kaneko, K., Kawakami, S., Miyoshi, M., Abukawa, T., Yamanaka, S., Mochizuki, M., and Yoshihara, S. (1997). Effect of retained placenta on subsequent bacteriological and cytological intrauterine environment and reproduction in Holstein dairy cows. Theriogenology, 48(4), 617-624.

Laven, R. A., and Peters, A. R. (1996). Bovine retained placenta: aetiology, pathogenesis and economic loss. Veterinary Record, 139(19), 465-471.

LeBlanc, S. J., Duffield, T. F., Leslie, K. E., Bateman, K. G., Keefe, G. P., Walton, J. S., and Johnson, W. H. (2002). Defining and diagnosing postpartum clinical endometritis and its impact on reproductive performance in dairy cows. Journal of dairy science, 85(9), 2223-2236.

Narasimhan, K. S. and Deopurkar, V. L. (1994). Accidents and diseases incidental to parturition. In: Sane, C. R. (Eds.). Reproduction in farm animals. (2nd Edn.) Varghese Publishing House, Bombay, India.

Parmar, S. V., Borthakur, A., Yadav, V. and Ravikanth, K. (2017). Efficacy
Evaluation of Herbal oral Liquid in Improving the Uterine Health and Augmenting Reproductive Performance in Dairy Cows. International journal of development research, 07(06), 13469-13471.

Perumal, P., Veeraselvam, M., and Nahak, A. K. (2013). Herbal Treatment in Animal Reproduction. International journal of Bio-resource and Stress Management, 4(3), 460-467.

Peters, A. R. and Laven, R. A. (1996). Treatment of bovine retained placenta and its effects. Veterinary Record, 139(22), 535-539.

Snedecor, G.W. and Cochran, W.G. (1994). Statistical methods. 8th ed. Iowa: Iowa State University press. 1-503.

Srinivas, T., Naidu, K. S., Brahmaiah, K. V., Rao T. S. C. S. and Kumar, P. R. (1998). Retained foetal membranes in crossbred cows - herbal treatment and uterine involution. Indian Journal of Animal Reproduction, 19, 26-28.

Tucho, T. T., and Ahmed, W. M. (2017). Economic and reproductive impacts of retained placenta in dairy cows. Journal of Reproduction and Infertility, 8(1), 18-27.

Walia, R., Ravikanth, K., Maini, S., and Sood, D. (2010). Therapeutic efficacy of AV/UTL/17 in cases of post-partum gynaecological disorders in cows: a field study. Veterinary World, 3(12), 544.

\section{How to cite this article:}

Anil D. Patil, Sunil K. Sahatpure, Dinesh V. Patil, Ravikanth Kotagiri and Bhaskar Ganguly. 2020. Comparative Evaluation of Some Herbal Therapies for Retained Placenta in Dairy Cows. Int.J.Curr.Microbiol.App.Sci. 9(10): 255-260. doi: https://doi.org/10.20546/ijcmas.2020.910.033 